\title{
ATG16L1 wt Allele
}

National Cancer Institute

\section{Source}

National Cancer Institute. ATG16L1 wt Allele. NCI Thesaurus. Code C119724.

Human AT G16L1 wild-type allele is located in the vicinity of 2 q37.1 and is approximately $86 \mathrm{~kb}$ in leng th. This allele, which encodes autophagy-related protein 16-1, is involved in the formation of autophagosomes. Mutation of the gene is associated with Crohn disease (inflammatory bowel disease 10). 